Jurnal Inkofar * Volume 1 No. 1 Juli 2019 * ISSN: 2615-3645 (Print) / 2581-2920 (Online)

Tersedia secara online di: http://www.politeknikmeta.ac.id/meta/ojs/

\title{
PENGELOLAAN JARINGAN HOTSPOT MENGGUNAKAN MIKROTIK ROUTER OS PADA PT ARSEN KUSUMA INDONESIA
}

\author{
Syifa Nur Rakhmah ${ }^{1}$, Icuk Maris Kuncoro ${ }^{2}$, Hani Harafani ${ }^{3}$ \\ ${ }^{1}$ Sistem Informasi / STMIK Nusa Mandiri Jakarta / syifa.snk@nusamandiri.ac.id \\ ${ }^{2}$ Teknik Informatika / STMIK Nusa Mandiri Jakarta / icukmari0910@nusamandiri.ac.id \\ ${ }^{3}$ Teknik Informatika / STMIK Nusa Mandiri Jakarta / hani.hhf@nusamandiri.ac.id
}

\begin{abstract}
The computer network at Arsen Kusuma Indonesia is still designed using conventional wired networks using the star network type. By looking at the problems that exist in PT Arsen Kusuma Indonesia with a lack of management of hotspot networks so that the author designed the network by applying microtic which will be used for regulation in sharing bandwidth as needed at PT Arsen Kusuma Indonesia. The method used to design computer networks using the Network Development Life Cycle (NDLC) model. The results of this thesis are that all computer networks can be managed with proxy and access points that act as access to networks that can deny access that is not nourished to the computer network. This results in good management of hotspot networks at PT Arsen Kusuma Indonesia, so that employees are not disturbed in doing work when the internet network is in an unstable condition.
\end{abstract}

Keyword: Microtic, Access point, Router

\section{ABSTRAK}

Jaringan computer pada PT Arsen Kusuma Indonesia masih di rancang menggunakan jaringan kabel konvensional yaitu dengan menggunakan tipe jaringan star. Dengan melihat permasalahan yang ada pada PT Arsen Kusuma Indonesia dengan kurangnya pengelolaan jaringan hotspot sehingga penulis merancang jaringan dengan menerapakan mikrotik dengan topologi jaringan tree yang akan digunakan untuk pengaturan dalam melakukan pembagian bandwidth sesuai kebutuhan pada PT Arsen Kusuma Indonesia. Metode yang digunakan untuk merancang jaringan computer dengan menggunakan model Network Development Life Cycle (NDLC). Hasil dari penelitian ini adalah semua jaringan computer dapat di manajemen dengan mikrotik dan access point yang berperan sebagai akses masuk dan keluarnya penggunaan jaringan yang dapat menolak akses yang tidak diiziinkan masuk pada jaringan computer. Hal ini menghasilkan pengelolaan yang baik pada jaringan hotspot pada PT Arsen Kusuma Indonesia, sehingga karyawan tidak terganggu dalam melakukan pekerjaan saat jaringan internet sedang dalam kondisi tidak stabil. Karena pada jaringan yang dikelola terdapat pengelolaan bandwith yang lebih signifikan.

Kata Kunci: Mikrotik, Access point, Router

\section{PENDAHULUAN}

Berdasarkan pemaparan yang disampaikan (Rizfan: 2019) tentang perkembangan jaaringan, mulai dari tahun 1940 sampai dengan saat ini cukup siginifikan. Mulai dari perkembangan jaringan dengan batch processing tahun 1940, pengembangan TSS (Time Sharing System) tahun 1950, Distribution Processing tahun 1960, penggunaan TCP/IP untuk standarisasi jaringan pada tahun 1980an, lahirnya World Wide Web pada tahun 1990an, hingga tahun 2000an dengan perkembangan jaringan oleh industri jaringan terbesar yaitu CISCO dengan menggunakan teknologi Artificial Intelligence pada jaringan. PT Arsen Kusuma Indonesia merupakan penyedia jasa internet broadband. Berdiri sejak tahun 2005, sejak saat itu telah dipercaya memberikan layanan yang berkualitas bagi pelanggan korporat maupun personal. PT Arsen Kusuma Indonesia dalam menjalankan kegiatan operasioanal setiap harinya menggunakan 2 access point, di karenakan belum adanya manajemen yang baik pada PT Arsen Kusuma Indonesia trafic penggunaan access point sering mengalami masalah atau kendala saat menerima atau pengiriman data. Administrator pada PT Arsen Kusuma Indonesia sering mengalami kesulitan dalam mengawasi kinerja dari semua perangkat keras maupun computer yang 
terhubung. Selain jarak antar ruang yang cukup jauh, administrator terkadang bingung computer dan perangkat keras mana (access point) yang sedang mengalami masalah. Serta kurang terpeliharanya perangkat jaringan, sehingga dapat mengakibatkan kinerja jaringan menjadi terhambat.

Berdasarkan trafic dan pemakaian access point maka perlu adanya majemen wireless pada PT Arsen Kusuma Indonesia, hal ini sejalan dengan pernyataan (Rifai \& Sudibyo, 2018) permasalahan yang terjadi ialah semakin banyak wireless dan access point serta banyaknya user yang terkoneksi yang tidak dikelola dengan baik dan secara optimal maka akan mengakibatkan kinerja dari access point tersebut akan kurang optimal dan efektif.

Banyak cara untuk mengelola atau manajemen access point diantaranya dengan mengunakan controller access point system management (Rifai \& Sudibyo, 2018), metodologi PPDIOO (Fahlepi,dkk. 2017) dan menggunakan Mikrotik Router (Suryanto, 2018) MikroTik Router adalah salah satu sistem operasi yang dapat digunakan sebagai router jaringan yang handal, mencakup berbagai fitur lengkap untuk jaringan dan wireless. (Riadi, 2011). Kelebihan yang lainnya dari Mikrotik Router juga murah, handal dalam melakukan kerjanya sebagai router.

Untuk itu penulis merancang sistem manajemen jaringan wireless pada PT Arsen Kusuma Indonesia menggunakan mikrotik router os yang dapat mempermudah koneksi internet. Manfaat selanjutnya adalah PT Arsen Kusuma Indonesia dapat melakukan pengelolaan maupun manajemen pada wireless access point (hostpot) sehingga terjadi lalu lintas jaringan dapat di kelola dengan baik. Serta dapat mengatur dan mengetahui alokasi bandwidth untuk akses jaringan local dan internet pada client dalam sebuah jaringan computer.

\section{METODE PENELITIAN}

Berdasarkan referensi Pamuji, dkk (2017) definisi sejumlah model pengembangan system yang ada, dalam penelitian ini, penulis menggunakan metode pengembangan system NDLC (Network Development Life Cycle). NDLC merupakan model yang mendefinisikan siklus proses perancangan atau pengembangan suatu system jaringan computer. NDLC mempunyai elemen yang mendefinisikan fase, tahapan, langkah atau mekanisme proses spesifik.

NDLC mendefinisikan siklus proses yang berupa fase atau tahapan dari mekanisme dari mekanisme yang dibutuhkan dalam suatu rancangan proses pembangunan atau pengembangan suatu system jaringan computer, terkait dengan penelitian ini, penerapan dari setiap tahap NDLC adalah sebagai berikut:

\subsection{Metode Pengembangan Sistem}

Metode yang dilakukan untuk pengumpulan data menurut (Purwanto \& Badrul, 2016) sebagai berikut:

1. Observasi

Penulis melakukan pengamatan langsung mengadakan kunjungan dan menganalisa jaringan computer yang ada di PT Arsen Kusuma Indonesia.

2. Wawancara

Untuk mendapatkan informasi yang diperlukan dalam melakukan penelitian ini penulis melakukan wawancara pada supervisor bagian IT pada PT Arsen Kusuma Indonesia.

\section{Studi Pustaka}

Metode ini merupakan cara untuk mendapatkan data-data secara teoritis sebagai bahan penunjang dalam penyusunan penelitian dengan cara mempelajari, meneliti dan menelaah berbagai literatur-literatur dari perpustakaan maupun dari buku jaringan, reverensi dari jurnal yang berkaitan dengan judul mikrotik router.

\subsection{Analisa Penelitian}

Tahap awal ini dilakukan analisa kebutuhan, analisa permasalahan yang muncul, analisa keinginan pengguna, dan analisa topologi jaringan yang sudah ada saat ini. Metode ini pula yang dilakukan oleh Rakhmah (2017) pada penelitian sebelumnya dengan menggunakan metode waterfall dalam melakukan analisa penelitian. Metode yang digunakan pada tahap ini diantaranya:

1. Analisis

Menelaah setiap data yang didapat dari data-data sebelumnya, maka perlu dilakukan analisa data tersebut untuk masuk ke tahap berikutnya.

2. Desain

Dari data yang sudah dianalisa pada tahap sebelumnya, pada tahap ini memberikan usulan yang dimaksudkan untuk lebih meningkatkan performansi, efisien dan efektifitas dari jaringan. 
Adapun usulan yang diberikan berupa desain mengenai perangkat yang menggunakan mikrotik router, topologi star, skema yang digunakan dengan menggunakan 2 access point yang digunakan sebagai manajemen jaringan.

3. Testing

Dalam tahap simulasi prototype ini pada tahap pengujian awal akses internet pad PT Arsen Kusuma Indonesia sering terjadi kendala dikarenakan belum adanya manajemen ynang mengaturnya. Dan setelah dilakukan pengujian akhir dengan menggunakan mikrotik router os yang digunakan untuk memanajemen jaringan yang ada pada PT Arsen Kusuma Indonesia jaringan dapat mudah di kelola dengan baik.

4. Implementasi

Dalam implementasi penulis akan menerapkan semua yang telah direncanakan dan di design sebelumnya. Implementasi merupakan tahapan yang sangat menentukan dari berhasil maupun gagalnya project yang akan dibangun.

5. Monitoring

Setelah implementasi tahapan monitoring merupakan tahapan yang penting, agar jaringan computer dan komunikasi dapat berjalan sesuai dengan keinginan dan tujuan awal dari user pada tahap awal analisis, maka perlu dilakukan kegiatan monitoring. Monitoring bisa berupa melakukan pengamatan pada:

a. Memantau traffic yang berjalan di jaringan sudah sesuai dengan semestinya.

b. Melihat koneksi yang aktif pada jaringan

\section{ANALISA HASIL DAN PEMBAHASAN}

3.1. Skema Jaringan Berjalan

Pada perusahaan PT Arsen Kusuma Indonesia yang bertepat didaerah Komplek PLN Duren Tiga perusahaan yang berjalan dibidang ISP yaitu menggunakan Topologi star, berikut topologi yang berada di PT Arsen.

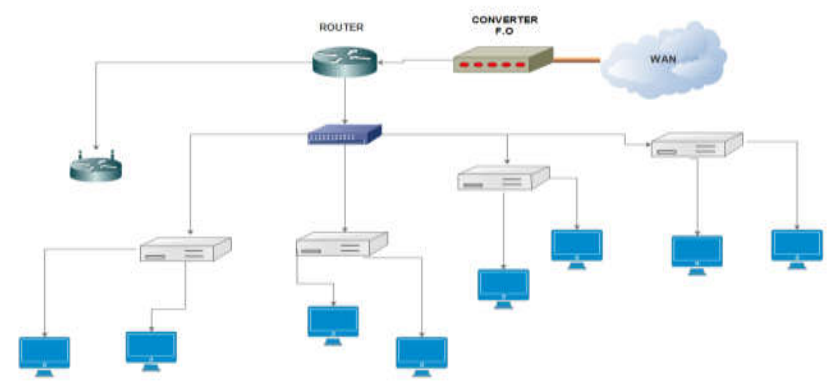

\section{Gambar III.1. Topologi PT Arsen Kusuma Indonesia (Sumber: PT Arsen Kusuma Indonesia)}

PT Arsen Kusuma Indonesia adalah sebuah perusahaan yang bergerak dibidang IT yaitu dalam melayani service: Colocation, Internet Bandwith, Wireless, Fiber Optic, Broker IP V4, Localloop, dan Manage Mail Server, berikut topology internal PT Arsen Kusuma Indonesia.

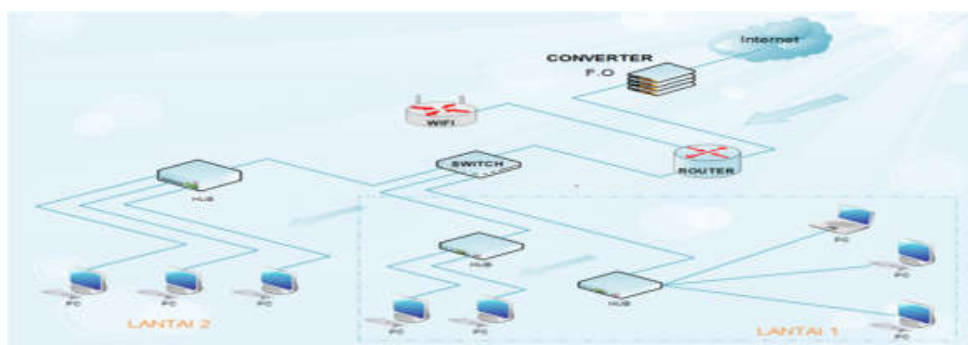

Gambar III.2. Topology Internal LAN PT Arsen Kusuma Indonesia (Sumber: PT Arsen Kusuma Indonesia) 
Pada kondisi jaringan sebelumnya, terlihat kondisi jaringan yang tidak stabil. Kondisi ini dapat mengakibatkan terkendalanya pekerjaan pada PT Arsen Kusuma Indonesia.

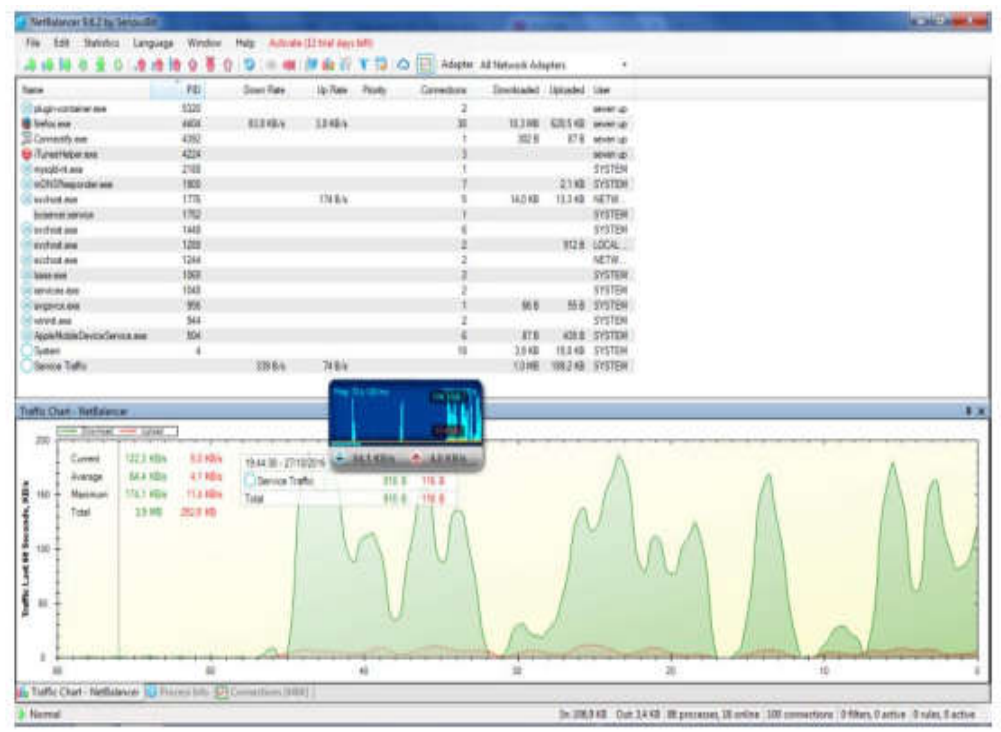

\section{Gambar III. 3 Traffic Jaringan Sebelum Pengelolaan Jaringan (Sumber: PT Arsen Kusuma Indonesia)}

Di bawah ini terlihat pula rate bandwith yang tidak merata pada penggunaan jaringan pada masingmasing IP Address User.

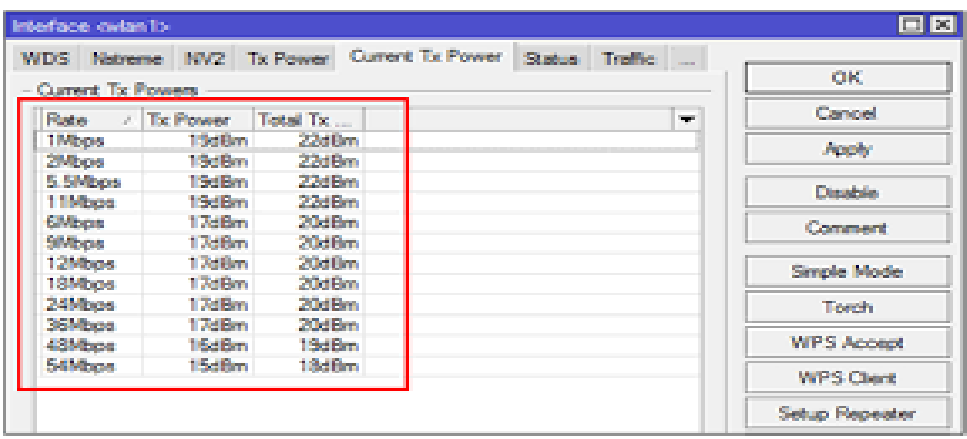

Gambar III.4 Rate Bandwith Sebelum Pengelolaan Jaringan (Sumber: PT Arsen Kusuma Indonesia)

\subsection{Keamanan Jaringan PT Arsen Kusuma Indonesia}

Pada penelitian ini penulis menganalisa keamanan jaringan pada PT Arsen Kusuma Indonesia antara lain sebagai berikut:

1. Firewall

Pada Perusahaan PT Arsen Kusuma Indonesia di setiap perangkat router mempunyai firewall untuk melakukan blocking apabila ada ip yang tidak dikenal maupun bersifat Distributed Denial of Service attacks (DDOS) dari luar untuk melakukan gangguan pada jaringan internal PT Arsen Kusuma Indonesia.

2. Anti Virus

Pada Perusahaan PT Arsen Kusuma Indonesia di setiap computer user menggunakan anti virus Kaspersky serta bawaan dari windows yaitu microsoft security essentials dan setiap computer user dilakukan permberian password yang berbeda-beda. 


\subsection{Permasalahan Pada Jaringan Sebelumnya}

Permasalahan jaringan yang terjadi di PT Arsen Kusuma Indonesia antara lain sebagai berikut:

1. Administrator sering kali kesulitan dalam mengawasi kinerja dari semua perangkat keras maupun computer yang terhubung. Selain jarak antar ruang yang cukup jauh, administrator terkadang bingung computer dan perangkat keras mana yang sedang mengalami masalah.

2. Kurangnya koordinasi internet ke setiap lantai menyebabkan informasi dan komunikasi bagi setiap pegawai agak cukup lambat.

3. Kurang terpeliharanya infrastruktur jaringan, yang dapat menyebabkan perangkat-perangkat penunjang pekerjaan akan lebih cepat mengalami kerusakan, sehingga pekerjaan dengan menggunakan internet menjadi terhambat.

\subsection{Alternatif Penyelesaian Masalah}

Adapun untuk menyelesaiakan pemecahan masalah dari permasalahan yang penuslis ulas diatas, sebagai berikut:

1. Melakukan monitor resource perangkat Router Jaringan PT Arsen Kusuma Indonesia apabila terjadi overload dengan menerapkan aplikasi Winbox.

2. Adanya pembagian bandwidth yang teratur untuk setiap user.

3. Melakukan pemeliharaan jaringan setiap waktu dengan memberikan access pada administrator jaringan.

\subsection{Manajemen Jaringan Usulan}

Setelah penulis menganalisa sistem jaringan yang berjalan pada PT Arsen Kusuma Indonesia, maka penulis mengusulkan sebuah jaringan mengunakan router mikrotik untuk mekakukan pembagian bandwidth dan mengoptimalkan kinerja acces point. Dan di fungsikan untuk menbuat akses masuk internet pada PT Arsen Kusuma Indonesia agar dapat membatasi user yang masuk pada jaringan internetnya.

Dengan menggunakan router mikrotik untuk yang di usulankan penulis di harapkan dapat membantu akses jaringan internet pada PT Arsen Kusuma Indonesia agar lebih optimal, serta dapat memonitoring jaringan agar lebih aman.

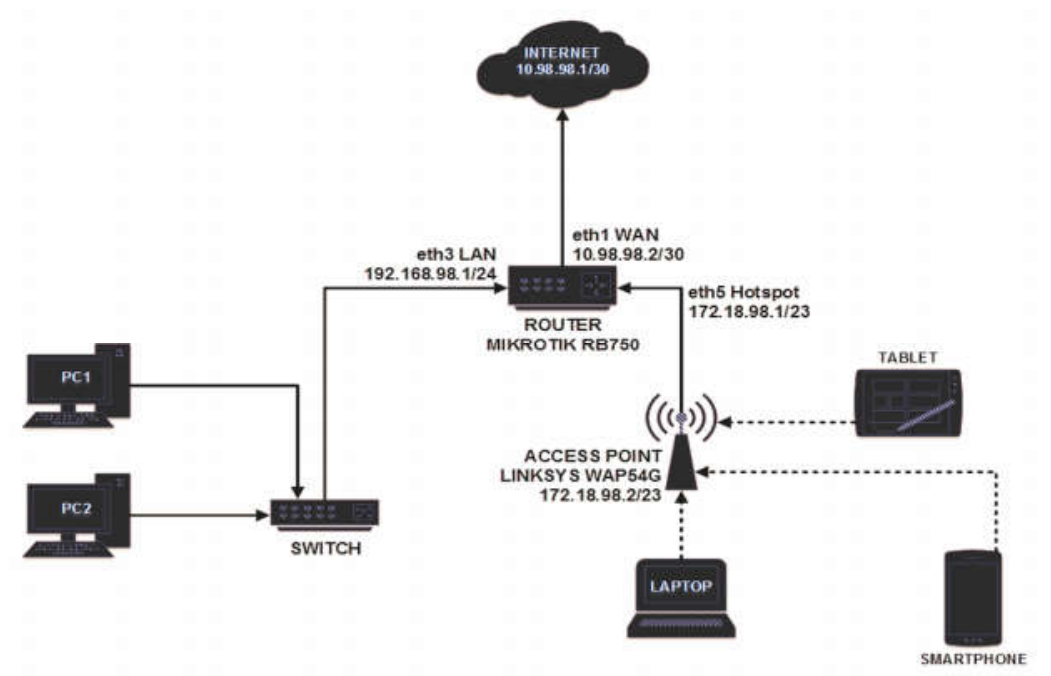

Gambar III.5. Topologi Jaringan Usulan

Gambar diatas adalah bentuk usulan topologi jaringan yang akan diimplementasikan pada PT Arsen Kusuma Indonesia, penulis tidak akan merubah bentuk topologi yang sudah ada pada PT Arsen Kusuma Indonesia, hal ini karena bentuk topologi yang ada sekarang sudah sangat baik. Topologi star yang ada pada PT. Arsen Kusuma Indonesia sudah sesuai dengan apa yang di butuhkan. 


\subsection{Skema Jaringan Usulan}

Pada skema jaringan usulan ini penulis menggambarkan secara detail dalam dalam IP Address hanya tidak meletakkan seluruh perangkat computer. Dalam topologi ini, router mikrotik bertindak sebagai pembagi koneksi internet ke jaringan kabel (LAN) dan jaringan nirkabel (WLAN/ Hotspot).

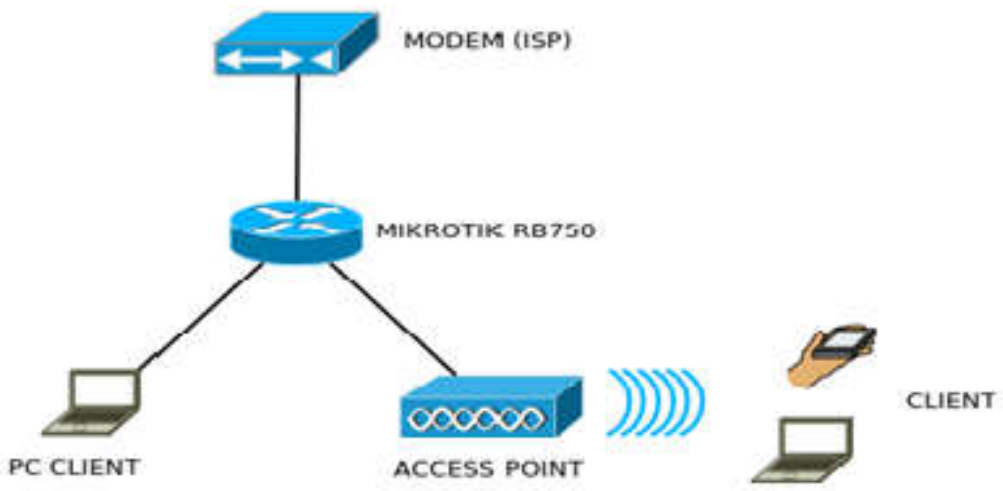

Gambar III.6. Skema Jaringan Usulan

\subsection{Keamanan Jaringan Usulan}

Untuk keamanan jaringan yang diterapkan pada PT Arsen Kusuma Indonesia menurut penulis sudah cukup bagus. Di karenakan adanya mikrotik router os yang berfungsi sebagai manajemen yang dapat membatasi pengguna khususnya yang hanya memiliki username dan password saja yang dapat menggunakan fasilitas internet. Sehingga masalah keamanan khususnya dari pihak luar dapat diminimalisir.

\subsection{Rancangan Aplikasi}

Dalam rancangan aplikasi penulis merancang dan mengimplementasikan jaringan dengan menggunakan mikrotik router os yang akan dihubungkan dengan pc atau laptop serta wifi yang akan saling terkoneksi. Sehingga jaringan yang ada pada PT Arsen Kusuma Indonesia dapat di manajemen dengan baik.

\subsection{Pengujian Jaringan}

Dalam hal membangun jaringan computer perlu dilakukan sebuah pengujian terhadap jaringan yang telah dibangun sebelumnya, hal ini berguna untuk memastikan bahwa semua sistem yang dibuat dapat berjalan dangan baik dan sesuai yang telah direncanakan sebelumnya.

1. Pengujian Awal

Pada sub ini akan dilakukan beberapa pengujian diantaranya tes koneksi dari admin mikrotik ke client 1 , dan dari admin router ke client 2 dengan cara ping.

1. Ping dari admin mikrotik ke client 1

Pada pengujian ini penulis mencoba melakukan tes koneksi dari admin mikrotik ke client 1 dengan cara ping IP address 10.20.30.251 yang merupakan IP address dari client 1 .

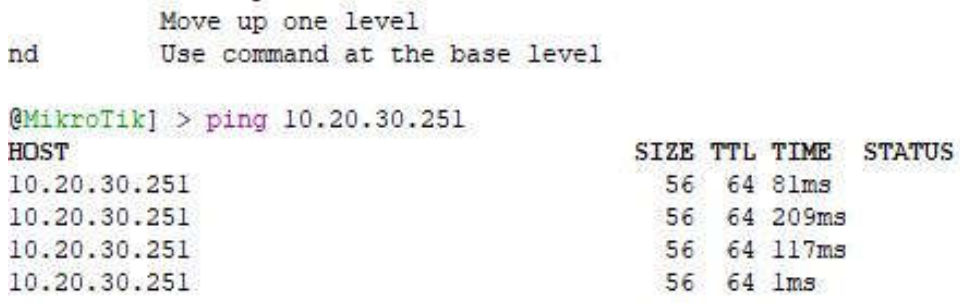

\section{Gambar III.7. Ping dari admin mikrotik ke client 1}




\section{PENUTUP}

Manajemen jaringan dengan menggunakan mikrotik router OS pada PT Arsen Kusuma Indonesia dapat membangun jaringan internet dengan biaya yang relatif murah dengan menggunakan mikrotik router. Terdapat perbandingan yang cukup signifikan pada jaringan yang belum dilakukan pengelolaan dengan jaringan yang sudah dilakukan pengelolaan menggunakan Winbox, jaringan lebih stabil dan terkelola dengan baik. Pada sistem keamanannya tidak kalah dengan jaringan dengan biaya yang mahal, karena dengan penyetingan keamanan oleh bagian jaringan sudah cukup aman. Pengoperasian mikrotik dengan menggunakan winbox, maka mempermudah IT Administrator untuk melakukan konfigurasi pada jaringan. Dengan adanya mikrotik, maka diketahui adanya PC yang tidak dapat melakukan koneksi atau sedang down. Untuk kedepannya diharapkan bisa bekerja sama dengan provider lain agar kelancaran penerimaan data jauh lebih baik lagi. Perlu ditambahkan bandwith untuk access point agar mempermudah karyaawan PT Arsen Kusuma Indonesia mendapatkan signal hotspot untuk mengakses internet.

\section{DAFTAR PUSTAKA}

Fahlepi, M. F., Ishwahyudi, C., \& Sutanta, E. (2017). Analisis Dan Perancangan Jaringan Nirkabel (WLAN) Studi Kasus Di Jogjakarta Montessori School Menggunakan Metodologi Ppdioo. Jurnal JARKOM, 6(1), 15-25.

Pamuji, S. A., Rachmawati, R. Y., \& Ishwahyudi, C. (2017). Analisis Dan Perancangan Jaringan Nirkabel Berbasis Captive Portal Menggunakan Simple Queue Pada Mikrotik Di Smp Al Azhar 26 Yogyakarta Septi. Jurnal JARKOM, 6(1), 44-53.

Purwanto, A. D., \& Badrul, M. (2016). Implementasi Access List Sebagai Filter Traffic Jaringan (Study Kasus PT. Usaha Entertainment Indonesia). Jurnal Teknik Computer Amik Bsi, II (1), 78-88.

Rakhmah, Syifa Nur. 2017. Sistem Informasi Perpustakaan Bebasis Web Pada Smk Negeri 2 Kota Bekasi. Jurnal Infokar. Vol 1, No 2 (2017). Diambil dari:

http://www.politeknikmeta.ac.id/meta/ojs/index.php/inkofar/article/view/11

Riadi, I. (2011). Optimalisasi Keamanan Jaringan Menggunakan Pemfilteran Aplikasi Berbasis Mikrotik Pendahuluan Landasan Teori. JUSI, Universitas Ahmad Dahlan Yogyakarta, 1(1), 71-80.

Rifai, B., \& Sudibyo, A. (2018). Manajemen Wireless Access point Pada Hotspot Server, 14(1), 111116.

Rifzan. (2019). Mengenal Sejarah Perkembangan Jaringan Computer Secara Singkat. https://www.robicomp.com/mengenal-sejarah-perkembangan-jaringan-computer-secarasingkat.html (3 Mei 2019)

Suryanto. (2018). Pengaturan Pemakaian Bandwidth Dan Akses Jaringan. Jurnal Ilmu Pengetahuan Dan Teknologi Computer, 3(2), 167-172. 